\title{
PERTANGGUNGJAWABAN PIDANA TERHADAP KECELAKAAN KAPAL AKIBAT TIDAK LAIK LAUT
}

\author{
Vicky Hanggara Alexandro \\ (Mahasiswa Program S1 Fakultas Hukum Universitas Tarumanagara)

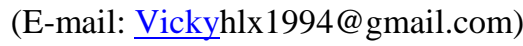

\section{Mety Rahmawati}

(Corresponding Author)

(Dosen Hukum Pidana Fakultas Hukum Universitas Tarumanagara, Meraih Gelar Sarjana dari

Fakultas Hukum Universitas Trisakti, Magister Hukum Dari Fakultas Hukum Universitas

Tarumanagara, dan Doktoral Hukum Dari Universitas Trisakti )

(E-mail: Metyargo@yahoo.com)

\begin{abstract}
Sea voyage is an important part for an archipelagic country like Indonesia to fulfill the people needs, either it's the main needs or supporting needs. The use of ships in Indonesia should be the main attention. Indonesia has regulate Undang-Undang Nomor 17 Tahun 2008 tentang Pelayaran, and many more regulations that regulate all matters relate to water transportation for goods and people. In practice of the law and the regulations that regulate the function and duty for each parties along with their responsibilities, that either directly related or not in the ship's operation. However, it doesn't create a secure and controlled conditions with the result that many ships in Indonesia are drowned, burn out, crash that casualties have taken many life as happened to KM Zahro Express, were drowned because the ship was not seaworthy to be operated, nevertheless the captain still sailed the ship, in this case the caption is blamed for, but in terms of seaworthy, not only the caption that is responsible but also the ship owner and the syahbandar take parts of the responsibilities. The questions which arise from this case is that how is the criminal liability of the ship owner towards a ship accident? The method that is being use in this study is normative research method and strengthened with data and interviews. Study data shows that in ship accident not only the caption that is responsible but also the syahbandar and the ship owner have the same responsibilities for the ship accident.
\end{abstract}

Keywords: criminal liability, ship accident 


\section{PENDAHULUAN}

\section{A. Latar Belakang}

Tujuh puluh persen bumi terdiri dari air yang meliputi lautan, sungai, dan lainlain, sedangkan yang tiga puluh persen merupakan daratan yang terpisah dalam bentuk benua dan pulau-pulau yang ada seperti saat ini. Ada beberapa negara yang berdiri di atas benua yang begitu luas di dalam satu daratan bisa berdiri dari puluhan negara, jikalau ada negara yang berdiri di dalam suatu benua terdapat juga negaranegara kepulauan seperti Islandia, Inggris, dan beberapa negara di Asia seperti Filipina, Jepang dan salah satunya adalah Indonesia yang merupakan negara kepulauan terbesar yang terletak di lintang khatulistiwa dan apit oleh dua benua Asia dan Australia serta diapit oleh Samudra Pasifik dan Samudra Hindia oleh karenanya disebut sebagai Nusantara. ${ }^{1}$

Indonesia sebagai negara Kepulauan yang memiliki struktur pulau-pulau yang tersebar luas dalam jumlah lebih dari 13.000 yang termasuk didalamnya pulau besar maupun pulau kecil, dengan garis pantai sepanjang $81.000 \mathrm{Km}$. Memberikan ciri khas sebagai negara Indonesia. $^{2}$ Indonesia sebagai negara kepulauan memiliki keanekaragaman potensi wisata di berbagai pulau-pulau yang tersebar di nusantara dimana untuk menjangkau pulau tersebut harus ditempuh dengan menggunakan angkutan laut. ${ }^{3}$ Di Indonesia, transportasi laut seharusnya menjadi primadona, karena terdapat pulau-pulau yang hanya dapat di hubungkan melalui transportasi laut. ${ }^{4}$ Berbeda dengan negara yang bukan kepulauan, transportasi laut tentunya tidak terlalu menjadi hal yang utama melainkan merupakan pilihan dari berbagai macam moda

\footnotetext{
${ }^{1}$ Hari Utomo, Jurnal: Siapa yang bertanggung jawab menurut hukum dalam kecelakaan kapal (Legally Responsible Parties In Ship Accident), http://ejurnal.peraturan.go.id/index.php/jli/article/download/75/pdf, hal 57, diakes 09 Juli 2018, pukul 10.38.

2 M. Daud Silalahi, Pengaturan Hukum Lingkungan Laut Indonesia dan Implementasinya Secara Regional, (Jakarta: Sinar Harapan, 1992), hlm. 66.

${ }^{3}$ Hari Utomo, Op.Cit. hlm. 58.

${ }^{4}$ Hari Utomo, Ibid.
} 
transportasi seperti kereta api, mobil, dan lainnya. Sedangkan negara kepulauan penggunaan transportasi darat tidak selalu membantu jika tidak ditunjang dengan moda transportasi laut, seperti halnya dalam penyebrangan sungai besar, selat, dan laut di negara tersebut.

Bukti-bukti yang menunjukan bahwa bangsa Indonesia telah menggunakan kapal-kapal sebagai alat transportasi penting untuk pemenuhan kebutuhan masyarakat dari segi penyaluran mengunakan transportasi laut, seperti yang tergores atau tergambar pada relief-relief Candi Borobudur dalam bentuk perahu-perahu bercadik yang telah mampu berlayar menuju sampai ke Pulau madagaskar (Afrika). Juga pembuatan perahu-perahu Pinisi yang dilakuan oleh orang-orang Makassar di Sulawesi Selatan. Teknologi dalam perancangan kapal di Indonesia mengalami perkembangan yang sangat besar setelah mendapat pengaruh dari luar. Dari para pelaut asing Indonesia memperoleh tambahan ilmu pengetahuan teknologi pelayaran, sehingga akhirnya Indonesia mempunyai Idustri kapal yang modern seperti sekarang ini. Sementara itu upaya-upaya yang dilakukan oleh pemerintah dalam bidang trasportasi laut antara lain merehabilitasi dan meningkatkan kapasitas infrastruktur yang ada, seperti pengadaan kapal pengangkut manusia dan kapal pengangkut barang, perbaikan pelabuhan-pelabuhan laut yang ada diIndonesia, terminal peti kemas dan dermaga-dermaga. Hal itu bertujuan untuk lebih memperlancar lintas laut antar pulau, meningkatkan perdagangan didalam negara maupun negara Internasional.

Sedemikian pentingnya transportasi laut Presiden Indonesia Joko Widodo memperkenalkan Progam Tol laut beliau berpendapat bahwa "Infrastruktur tol laut penting sekali, beliau contohkan, semen di Jawa harganya Rp 50-60 ribu. Tapi, di Papua bisa Rp 1 juta bahkan Rp 1,2 juta atau Rp 1,5 juta. Kalau tol laut dibangun, di Sumatera, Jawa, Kalimantan, Sulawesi, Papua, akan memberikan rasa keadilan. ${ }^{5}$

\footnotetext{
Dani Prabowo, Jokowi fokus bangun tol laut untuk pemerataan, https://nasional.kompas.com/read/2014/06/15/2140590/Jokowi.Fokus.Bangun.Tol.Laut.untuk.Pemerat aan, diakses 09 Juli, Pukul 11.28.
} 
Dalam negara kepulauan terutama di Indonesia transportasi laut merupakan salah satu cara untuk menyalurkan kebutuhan dari kebutuhan utama sampai dengan kebutuhan pelengkap atau penunjang. Tidak bisa dipungkiri bahwa sarana dan prasarana transportasi laut di Negara kepulauan seperti Indonesia telah menjadi pendukung utama dalam pergerakan penyeluran barang dalam jumlah besar dengan menggunakan kapal laut. Dari segi ekonomi dan bisnis penggunaan sarana transportasi dengan kapal laut lebih efektif dan besar manfaatnya. Sehingga dengan adanya sarana prasarana transportasi laut seperti kapal laut berguna untuk pemindahan barang-barang dan orang dari satu tempat ke tempat yang lainnya, diharapkan akan dapat diikuti oleh aktifitas ekonomi masyarakat yang berdampak baik dan positif dalam peningkatan ekonomi di wilayah-wilayah Indonesia.

Selain sebagai moda transportasi untuk penyaluran kebutuhan primer dan pelengkap untuk masyarakat baik dalam maupun di luar negara. Kebutuhan manusia untuk berpergian dari satu tempat ke tempat lainnya dengan tujuan mengambil kebutuhan-kebutuhan masing-masing, misalnya berbelanja, bekerja, sekolah, dan lain-lain. Dari segi jarak dan jenis transportasi kapal tentu di perhatikan oleh pemerintah misalnya kapal untuk pengangkutan barang antar pulau tentu berbeda dengan kapal penyeberangan selat, danau dan sebagainya. Hal ini menjadi perhatian penting bagi pemerintah untuk membentuk regulasi dalam rangka untuk mengatur hal-hal bagaimana pendaftaran kapal yang akan berlayar, jenis kapal yang sesuai dengan medan pelayarannya, selektif dalam merekrut nakhoda-nakhoda beserta awak-awak kapal yang professional sesuai dengan bidang nya.

Indonesia telah mengundangkan Undang-Undang Nomor 17 Tahun 2008 tentang Pelayaran, Peraturan Pemerintah Nomor 20 Tahun 2010 tentang Angkutan Perairan, Peraturan Menteri Perhubungan Nomor 20 Tahun 2015 tentang Standar Keselamatan Pelayaran dan masih banyak undang-undang dan peraturan-peraturan lain nya yang mengatur segala hal ikhwal yang berkaitan dengan lalu lintas lewat laut, pengangkutan barang dan atau orang melalui laut, kegiatan kenavigasian dan 
perkapalan sebagai sarana tranportasi laut termasuk aspek keselamatan serta penegakan hukumnya. ${ }^{6}$

Undang-undang Nomor 17 Tahun 2008 tentang Pelayaran, dalam Pasal 117 huruf (a) berbunyi: Keselamatan dan keamanan angkutan perairan yaitu kondisi terpenuhinya persyaratan:

1. kelaiklautan kapal;

2. kenavigasian.

yang pada ayat (2) dijelaskan lebih rinci mengenai kategori Kelaikkapal dijelaskan yang dimaksud pada ayat (1) huruf (a) wajib dipenuhi setiap kapal sesuai dengan daerah pelayarannya yang meliputi:

1. keselamatan dan keamanan kapal;

2. perhatian utama pencemaran dari kapal;

3. pengendalian kapal;

4. batas pemuat kapal dan pemuatan;

5. kesejahteraan anak buah kapal dan kesehatan penumpang;

6. status hukum kapal;

7. pengaturan keselamatan dan perhatian pencemaran dari kapal; dan

8. pengaturan keamanan kapal.

Pasal 117 ayat (3) yang menyatakan memenuhi semua standar persyaratan kelaik kapal sebagaimana dimaksud pada ayat (1) dibuktikan dengan sertifikat dan surat kapal, Pasal 122 berbunyi sebagai berikut: Setiap ppengendalian kapal dan pelabuhan harus memenuhi standar persyaratan keselamatan dan keamanan serta perlindungan lingkungan kelautan. Sampai pada ancaman sanksi yang ada pada Pasal 303 yang berbunyi:

1. Setiap orang yang mengoperasikan kapal dan pelabuhan tanpa memenuhi persyaratan keselamatan dan keamanan pelayaran serta perlindungan lingkungan maritim sebagaimana dimaksud dalam pasal

\footnotetext{
${ }^{6}$ Hari Utomo, Op.Cit.
} 
122, dipidana dengan pidana penjara paling lama 2 (dua) tahun dan denda paling banyak Rp. 300.000.000,00 (tiga ratus juta rupiah).

2. Jika perbuatan sebagaimana dimaksud pada ayat (1), mengakibatkan kerugian harta benda dipidana dengan pidana penjara paling lama 4 (empat) tahun dan denda paling banyak Rp. 500.000.000,00 (lima ratus juta rupiah).

3. Jika perbuatan sebagaimana dimaksud pada ayat (1) mengakibatkan kematian seseorang, dipidana dengan pidana penjara paling lama 10 (sepuluh) tahun dan denda paling banyak Rp. 1.500.000.000,00 (satu miliar lima ratus juta rupiah).

Dalam kasus kecelakaan kapal, baik yang terkait langsung maupun tidak langsung pun diberikan porsi pertanggungjawaban masing-masing. Tapi yang pasti, aturan ini tegas memberikan sanksi baik secara administratif maupun pidana terhadap pihak-pihak yang terbukti melanggar hal-hal yang dipersyaratkan. Sebagian hasil investigasi kecelakaan menunjukkan bahwa faktor kesalahan manusia (human error) seringkali menjadi penyebabnya.

Sebutlah yang pertama, Nakhoda. Peran orang yang punya jabatan tertinggi di antara anak buah kapal (ABK) ini sangat vital mulai dari dokumentasi perizinan kapal, memastikan kelaikan kapal sebelum layar, sampai terjadinya kecelakaan. Nakhoda diberikan tanggung jawab oleh UU Nomor 17 Tahun 2008 terkait keselamatan dan keamanan kapal. Sehingga apabila nakoda melanggar ketentuan UU Nomor 17 Tahun 2008 dapat terancam dengan pidana penjara dan pidana denda. Nakhoda wajib membuat buku catatan kapal (log book) yakni catatan yang berisi kondisi kapal terkait operasional kapal seperti kondisi kapal, kondisi teknis dari kapal yang mesti diperbaiki kalau ada yang rusak. Apabila ternyata kondisi kapal diketahui tidak layak, nakhoda berhak menolak melayarkan kapal, begitu pula sebaliknya.

Atas kondisi itu, dijelaskan dalam Pasal 138 ayat (3) UU Nomor 17 Tahun 2008 yaitu: Nakhoda berhak menolak untuk melayarkan kapalnya apabila mengetahui kapal tersebut tidak memenuhi persyaratan sebagaimana dimaksud pada ayat (2). Nakhoda memberitahukannya kepada pejabat pemeriksa keselamatan kapal. Bisa diperlukan, pemilik, operator kapal, dan nakhoda diminta turut membantu proses 
pemeriksaan-pemeriksaan dan pengujian kapal itu. tapi di sisi lain lazimnya si pemilik kapal kadangkala tidak menghiraukan hal ini. Namun pada Pasal 249 dijelaskan: Kecelakaan kapal berdasarkan Pasal 245 menjelaskan merupakan tanggung jawab Nakhoda kecuali dapat dibuktikan lain.

Ancaman pidana itu tak hanya buat Nakhoda, pemilik kapal pun juga berpotensi menjadi pesakitan lantaran kuasanya sebagai empunya kapal, pemilik atau perusahaan diberi tanggungjawab dan ancaman sanksi mengenai keselamatan dan keamanan pada Pasal 40 huruf (a) dan (b) Undang-undang Nomor 17 Tahun 2008 dijelaskan:

1. Perusahaan angkutan di perairan bertangggung jawab terhadap keselamatan dan keamanan penumpang dan/atau barang yang diangkutnya.

2. Perusahaan angkutan di perairan bertanggung jawab terhadap muatan kapal sesuai dengan jenis dan jumlah yang dinyatakan dalam dokumen muatan dan/atau perjanjian atau kontrak pengangkutan yang telah disepakati.

Tidak hanya itu pada Pasal 305: "Setiap orang yang tidak memelihara kapalnya sehingga tidak memenuhi sesuai persyaratan keselamatan kapal sebagaimana dimaksud dalam Pasal 130 ayat (1), dipidana dengan pidana penjara paling lama 6 (enam) bulan atau denda paling banyak Rp100.000.000,00 (seratus juta rupiah)." Selain dari pada Undang-undang Nomor 17 Tahun 2008 Tentang Pelayaran tersebut Pasal 58 Undang-undang Nomor 51 Tahun 2002 Tentang Perkapalan berbunyi:

1) Pemilik, operator, nakhoda atau pemimpin kapal wajib memelihara dan merawat kapalnya sehingga kapal selama dioperasikan tetap memenuhi persyaratan keselamatan kapal dan sesuai dengan data yang terdapat pada sertifikat kapal.

2) Setiap kapal wajib dilimbungkan sesuai dengan jadwal yang ditentukan untuk pelaksanaan pemeliharaan sebagaimana dimaksud dalam ayat (1).

3) Ketentuan lebih lanjut mengenai pemeliharaan dan perawatan sebagaimana dimaksud dalam ayat (1) dan ayat (2) diatur dengan Keputusan Menter. 
Dalam melaksanakan fungsi dan tugas keselamatan dan keamanan kapal, pemerintah dalam hal ini adalah syahbandar diberikan fungsi dan tugas sebagaimana diatur dalam pasal 208 Undang-undang Nomor 17 Tahun 2008 tentang 2008 berbunyi:

1. Dalam melaksanakan fungsi keselamatan dan keamanan sebagaimana dimaksud dalam Pasal 207 ayat (1) Syahbandar mempunyai tugas:

a. memperhatikan kelaikkapal, keselamatan, keamanan dan ketertiban di pelabuhan;

b. perhatian tertib perjalanan kapal di perairan pelabuhan dan lalu lintas pelayaran;

c. memperhatikan kegiatan-kegiatan alih batas muat di perairan pelabuhan;

d. memperhatikan kegiatan salvage dan pekerjaan bawah air;

e. memperhatikan kegiatan pemberhatian kapal;

f. memperhatikan pemanduan;

g. memperhatikan turun naik muat barang berbahaya serta limbah bahan berbahaya dan beracun;

h. memeperhatikan pengisian bahan bakar kapal;

i. memperhatikan ketertiban embarkasi dan debarkasi penumpang;

j. memperhatikan pengerukan dan reklamasi pulau;

k. memperhatikan kegiatan pembangunan fasilitas pelabuhan untuk kapal;

1. melaksanakan bantuan pencarian dan penyelamatan kecelaan kapal;

m. memimpin regu penanggulangan pencemaran dan pemadaman kebakaran di pelabuhan; dan

n. memperhatikan pelaksanaan perlindungan lingkungan kelautan;

tentu syahbandar dalam melaksankan fungsi dan tugasnya yang diamanatkan oleh Undang-undang harus bisa mempertanggungjawabkan tugas dan fungsinya.

Dalam prakteknya undang-undang dan regulasi-regulasi yang sudah mengatur fungsi dan tugas masing-masing pihak serta pertanggungjawaban oleh pihak-pihak yang berkaitan langsung maupun tidak dalam pengoperasian kapal. Namun tidak menciptakan keadaan-keadaan yang seharusnya aman dan terkendali sehingga banyak kapal-kapal di Indonesia yang tenggelam, terbakar, tabrakan yang memakan 
korban hingga ratusan nyawa seperti yang terjadi di danau Toba, akibat muatan penumpangnya melebihi kapasitas penumpang yang seharusnya. Begitu juga dengan kapal KM Zahro Express yang melayani penyeberangan dari perairan Muara Angke, pelabuhan Dis Hub Kaliadem, Jakarta Utara menuju Pulau Tidung, Kepulauan Seribu Jakarta Utara tenggelam akibat kapal yang tidak laik untuk dioperasikan namun nakhoda tetap melayarkan kapal tersebut dalam hal ini nakhoda yang disalahkan tetapi dalam hal kelaikan kapal bukan hanya nakhoda yang bertanggungjawab akan tetapi pemilik kapal serta syahbandar juga ikut bertanggungjawab, korban meninggal dalam insiden tersebut hingga 20 orang.

Melihat fakta demikian, peraturan yang sudah ada berbanding terbalik dengan kasus yang terjadi. Regulasi yang telah dibuat secara rinci tentang hukuman dan tanggungjawab masing-masing pihak baik nakhoda, perusahaan kapal dan syahbandar namun tetap tidak sesuai dengan standar keselamatan transportasi. Berdasarkan penjelasan latar belakang di atas, maka diangkatlah judul penelitian ini “Pertanggungjawaban Pidana Terhadap Kecelakaan Kapal Akibat Tidak Laik Laut".

\section{B. Permasalahan}

Berdasarkan penjabaran latar belakang masalah di atas, permaslahan yang dikaji dalam penelitian ini adalah bagaimana pertanggungjawaban pidana terhadap kecelakaan kapal akibat tidak laik laut?

\section{Metode Penelitian}

Penelitian hukum adalah suatu proses untuk menemukan aturan hukum, prinsip-prinsip hukum, maupun doktrin-doktrin hukum guna menjawab isu hukum yang dihadapi. ${ }^{7}$

\section{Jenis Penelitian}

\footnotetext{
${ }^{7}$ Peter Mahmud Marzuki, Penelitian Hukum, (Jakarta: Kencana, 2006), hal. 83
} 
Jenis penelitian dalam skripsi ini menggunakan metode penelitian hukum normatif, yaitu suatu prosedur penelitian ilmiah untuk menemukan kebenaran berdasarkan logika keilmuan hukum dari sisi normatif. ${ }^{8}$ Pada penelitian hukum normatif ini lebih difokuskan untuk mengkaji penerapan kaidah-kaidah atau norma-norma dalam hukum positif, terutama yang berkaitan dengan pertanggungjawaban pidana terhadap kecelakaan kapal yang menyebabkan hilangnya nyawa berdasarkan standar keselamatan transportasi.

\section{Jenis Data}

Dalam penelitian hukum normatif atau kepustakaan teknik pengumpulan data yang digunakan adalah studi pustaka terhadap bahan-bahan hukum, baik bahan hukum primer, bahan hukum sekunder maupun bahan hukum tersier dan atau bahan non-hukum. ${ }^{9}$

1. Bahan-bahan hukum primer berupa peraturan perundangundangan, seperti:

1) Kitab Undang-Undang Hukum Pidana Nomor 1 Tahun 1946 (Lembaran Negara Tahun 1958 Nomor 127).

2) Undang-Undang Nomor 17 Tahun 2008 tentang Perlayaran (Lembaran Negara Republik Indonesia Tahun 2008 Nomor 64 dan Tambahan Lembaran Negara Republik Indonesia Nomor 4849).

3) Peraturan Pemerintah Nomor 1 Tahun 1998 tentang Pemeriksaan Kecelakaan Kapal (Lembaran Negara Republik Indonesia Tahun 2004 Nomor 21 dan Tambahan Lembaran Negara Republik Indonesia Nomor 4369.

\footnotetext{
8 Johnny Ibrahim, Teori \& Metodologi Penelitian Hukum Normatif, (Malang: Bayumedia Publishing, 2006), hlm. 57.

9 Mukti Fajar dan Yulianto Achmad, Dualisme Penelitian Hukum Normatif \&Empiris, cetakan ke-3, (Yogyakarta: Pustaka Pelajar, 2015), hlm. 160.
} 
4) Peraturan Pemerintah Nomor 7 Tahun 2000 tentang Kepelautan (Lembaran Negara Republik Indonesia tahun 2000 Nomor 13 dan Tambahan Lembaran Negara Republik Indonesia).

5) Peraturan Pemerintah Nomor 51 Tahun 2002 tentang Perkapalan (Lembaran Negara Republik Indonesia tahun 2002 Nomor 95 dan Tambahan Lembaran Negara Republik Indonesia Nomor 4227).

6) Peraturan Pemerintah Nomor 5 Tahun 2010 tentang Kenavigasian (Lembaran Negara Republik Indonesia tahun 2010 Nomor 8 dan Tambahan Lembaran Negara Republik Indonesia Nomor 5093).

7) Peraturan Pemerintah Nomor 20 Tahun 2010 tentang Angkutan Perairan (Lembaran Negara Republik Indonesia tahun 2010 Nomor 26 dan Tambahan Lembaran Negara Republik Indonesia Nomor 5108).

8) Peraturan Menteri Perhubungan Tahun 20 Tahun 2015 tentang Standar Keselamatan Pelayaran.

9) Peraturan Menteri Perhubungan Nomor 25 Tahun 2015 tentang Standar Keselamatan Transportasi Sungai, Danau, dan Penyeberangan.

2. Bahan-bahan hukum sekunder yaitu buku-buku hukum termasuk skripsi, tesis, dan disertasi hukum dan jurnal-jurnal hukum. Disamping itu juga, kamus-kamus hukum, dan komentar-komentar 
atas putusan pengadilan. ${ }^{10}$ berkaitan dengan obyek penelitian, yang berhubungan dengan penulisan.

3. Bahan-bahan hukum tersier yaitu bahan yang memberikan informasi tentang bahan hukum primer dan bahan hukum sekunder, seperti: kamus hukum, dan kamus bahasa.

Bahan Non-Hukum, di dalam penelitian hukum keperluan akademis pun bahan nonhukum dapat membantu. Seperti wawancara.

\section{Teknik Analisis data}

Teknik analisis data yang dipakai untuk penelitian ini yaitu metode analisis deduktif, yaitu metode analisis data yang dimulai dari dalil-dalil umum postulat dan paradigma tertentu sebagai pangkal tolak pengambilan kesimpulan.

\section{Pendekatan Penelitian}

Pendekatan penelitian yang digunakan untuk dalam penulisan ini adalah pendekatan undang-undang (statute approach). Pendekatan undang-undang (statute approach) dilakukan dengan menelaah semua undang-undang dan regulasi yang bersangkut paut dengan isu hukum yang sedang ditangani. ${ }^{11}$

Adapun penelitian yang dilakukan lebih ditujukan kepada pendekatan undangundang dan regulasi-regulasi dikaitkan dengan adanya kasus kapal tenggelam.

\section{Sifat Penelitian}

Penelitian yang dilakukan bersifat deskritif yaitu menggambarkan gejalagejala dilingkungan masyarakat terhadap suatu kasus yang merupakan tata cara penelitian yang dihasilkan data deskriptif. ${ }^{12}$ Penulis berharap untuk dapat lebih jauh meneliti serta memberikan data yang diteliti tentang objek yang diteliti ini adapun penulis ingin memberikan deskrisi mengenai standar keselamatan yang diatur didalam Undang-Undang.

${ }^{10}$ Peter Mahmud Marzuki, penelitian hukum edisi revisi, (Jakarta: kencana prenada media grup, 2005), hlm. 195-196.

${ }^{11}$ Peter Mahmud Marzuki, Op.cit, hlm. 133.

${ }^{12}$ Soerjono Soekanto, Op. Cit, hlm. 32. 


\section{PEMBAHASAN}

\section{A. Hasil Penelitian}

Kasus terbakarnya kapal zahro express diberitakan di media Televisi dan koran pada tanggal 01 Januari 2017 seperti yang diberitakan bahwa kapal KM Zahro Express terbakar saat beranjak dari salah satu pelabuhan di Muara Angke menuju Pulau Tidung, Kepulauan seribu. Kasus terbakarnya kapal zahro express diawali akan di berangkatkannya kapal zahro express hendak berlayar menuju Pulau Tidung, Kepulauan Seribu Jakarta Utara yang dipimpin oleh MN selaku nakhoda kapal zahro express yang di ikuti oleh beberapa orang sebagai crew yaitu sdr. Samudin, sdr. Selamet, sdr. Suhardi, sdr. Subur, dan sdr. Misan sedangkan sdr. Misan dan sdr. Suhardi tidak ikut berlayar. Namun sdr. Tata yang namanya tidak terdaftar dalam crew list ikut berlayar, saudara MN selaku nakhoda menulis crew list dan master sailig declaration yang mana surat tersebut sebagai permohonan diterbitkannya surat persetujuan berlayar ( SPB ) oleh syahbandar untuk pemberangkatan kapal KM zahro express pada hari minggu tanggal 01 Januari 2017.

Atas pengajuan permohonan penerbitan dan menandatangani surat persetujuan SPB yang diajukan oleh MN ke kantor syahbandar kaliadem, Muara Angke, Jakarta utara kepada Giyat petugas syahbandar yang sedang piket pada waktu itu dan Giyat selaku petugas syahbandar menulis data-data yang ada di blanko yang tersedia serta mentandatangganinya berdasarkan data-data yang diterima dari MN. Dan diketahui bahwa daftar list penumpang dicatat oleh MN melalui penjualan tiket penumpang yang langsung beli dari $\mathrm{MN}$, setelah $\mathrm{MN}$ mencatat penjualan dan pemesana melalui $\mathrm{MN}$, kemudia MN menulis atau mengisi crew list untuk keberangkatan kapal KM zahro express pada hari minggu 01 Januari 2017 sekira pukul 08.15 WIB dari pelabuhan Dishub kaliadem-Jakarta Utara, pada saat permohonan penerbitan surat persetujuan berlayar yaitu pada hari minggu 07 Januari 2017 sekira pukul 07.30 Wib dikantor Dishub Kaliadem, Muara Angke-Jakarta Utara daftar penumpang KM zahro 
express untuk diberangkatkan tersebut dibuat dan di tandatanggani oleh MN serta membubuhkan cap stempel kapal KM zahro express.

Namun sebelum keberangkatan MN selaku nakhoda tida mengecek secara fisik baik secara manives, crew list maupun terhadap kelengkapan lainya dikarenakan sudah menjadi kebiasaan, padahal MN mengetahui dan menyadari bahwa apa yang tertuliskan di manivest dan crew list tidak sesuai dengan fisik aslinya, seharusnya MN mengecek secara fisik terlebih dahulu. Kemudian sdr. Misan yang mempunyai tugas dan tanggung jawab untuk mengumpulkan/tiket penumoang yang naik ke atas kapal zahro express, saat itu jumlah penupang KM zahro express yang masuk dan terdaftar dalam manivest ada 100 orang sedangkan yang selebihnya/sisanya 120 orang adalah penumpang KM hasbi jaya dan KM dolpin dengan menggunakan tiket KM hasbi jaya sebanyak 60 tiket/penumpang dan KM dolpin 60 orang/penumpang. Namun misan selaku penanggung jawab pengumpulan tiket tidak mengetahui siapa yang menulis manifest, namun pada awalnya sdr. Misan yang menulis nama-nama penumpang diselambar kertas di loket tempat penjualan tiket yaitu nomor 1 sampai 91. Sdr. Misan memasukan penumpang KM hasbi jaya karena diperbolehkan dan diperintahkan oleh sdr. Mutia prima yodi selaku pemilik kapal KM zahro express.

Sekira pukul 08.15 Wib KM zahro express berangkat dari pelabuhan Kali Adem Muara Angke Jakarta Utara dengan tujuan pulau tidung dengan jumlah penumpang KM lestari 100 orang/tiket ditambah 60 orang/tiket KM hasbi jaya dan 60 orang/tiket KM dolpin. Pada pukul 08.25 Wib sdr. Mutia prima yodi selaku pemilik kapal KM zahro express menyuruh sdr. Misan untuk menagih/memintah tiket penumpang dan diarahkan nagih dari depan lantai satu baru kebelakang. Beberapa menit belayar MN selaku Nakhoda kapal menyadari bahwa penumpang kapal KM zahro express lebih dari yang dicantumkan dimanifest yaitu sejumlah 100 orang, kemudia Mn menangil sdr. Misan untuk menanyakan berapa jumlah tiket yang ada dan berapa jumlahnya penumpang yang ada di atas kapal KM zahro express. Dan kemudia sdr. Misan menjelaskan memang ada perbedaan jumlah penumoang yang tercantum dalam 
manifest karena ada penumpang lain yang naik kapal KM zahro express yang menggunakan tiket kapal lain.

Bahwa pada pukul 08.30 tiba-tiba terdengar suara ledakan dari kamar mesin yang disambut dengan semburan api, namun api tidak dapat dikendalikan, para penumpang panik menyelamatkan diri dan berrebut keluar melalui pintu depan, namun tidak tertampung oleh pintu keluar yang mengakibatkan penumpang menumpuk sebelum dan setelah pintu depan kapal dan selanjutnya para penumpang sebagian terjun kelaut dan sebagian tertinggal di kapal dan ke samburan api. Selama dalam perjalanan MN selaku nakhoda tidak menjelaskan/menerangkan baik secara tertulis dan lisan ataupun diperagakan bagaimana menggunakan alat-alat keselamatan atapun letak alat keselamatan dan bagaimana cara menyelamatkan diri jika terjadi sesuatu hal yang tidak diinginkan seperti kapal karam atau kandas, kapal akan tenggelam atau terjadi kebakaran kepada penumpang. Akibat kejadian tersebut mengakibatkan 20 orang meninggal diatas kapal dan 3 orang dilaut, korban luka-luka sebanyak 21 orang.

\section{B. Analisis}

Undang-undang Nomor 17 Tahun 2008 Tentang Pelayaran mengatur begitu banyak fungsi, tugas dan wewenang syahbandar terkait keselamatan dan keamanan. Hampir semua kegiatan pelayaran dikendalikan dan tidak lepas dari pihak pemerintah dalam hal ini syahbandar. Namun jika dikaitkan dengan kronolgis kasus yang telah dijelaskan diatas bahwa pihak syabandar tidak melakukan tugas dan fungsinya dengan baik dalam hal pengawasan sehingga kapal KM zahro express yang dalam keadaan tidak laik laut bisa lolos untuk belayar.

Mengenai bagaimana pertangungjawaban pidana syahabandar memang di dalam Undang-undang Nomor 17 Tahun 2008 Tentang pelayaran dalam ketentuan pidana tidak mengatur bagaimana pertanggungjawaban pidana oleh syahbandar namun mengenai pertanggungjawaban secara pidana oleh pihak syabandar sesuai dengan kronologis diatas, syabandar memberikan izin berlayar kepada nakhoda kapal KM 
Zahro Express untuk berlayar padahal kapal tersebut tidak laiklaut. Didalam Undangundang Nomor 17 Tahun 2008 Tentang Pelayaran sudah mengatur segala fungsi, tugas dan wewenang dalam rangka pemenuhan syarat keselamatan dan keamanan. Syahbandar bertanggungjawab yang dimana ia seharusnya melakukan pengawasan namun pihak syahbandar tidak melakukannya sesuai dengan apa yang diperintahkan oleh Undang-undang Nomor 17 Tahun 2008 Tentang Pelayaran. Untuk menentukan pertanggungjawaban pidana harus mempunyai unsur-unsur:

1. Kemampuan bertanggung jawab atau dapatnya dipertanggungjawabkan dari si pembuat.

2. Adanya kaitan psikis antara pembuat dan perbuatan, yaitu adanya sengaja atau kesalahan dalam arti sempit (culpa). Pelaku mempunyai kesadaran yang mana pelaku seharusnya dapat mengetahui akan adanya akibat yang ditimbulkan dari perbuatannya.

3. Tidak adanya dasar peniadaan pidana yang menghapus dapatnya dipertanggungjawabkan sesuatu perbuatan kepada pembuat.

Dikatakan seseorang mampu bertanggungjawab bilamana seseorang keadaan jiwanya:

1. Tidak terganggu oleh penyakit terus-menerus atau sementara (temporair);

2. Tidak cacat dalam pertumbuhan (gagu, idiot, imbecile, dan sebagainya), dan

3. Tidak terganggu karena terejut, hypnotisme, amarah yang meluap, pengaruh bawah sadar/reflexe bewenging, melindur/slaapwandel, mengigau karena demam/ koorts, nyidamdan lain sebagainya. Dengan perkataan lain dia dalam keadaan sadar.

Kemampuan jiwanya:

1. Dapat menginsyafi hakekat dari tindakannya; 
2. Dapat menentukan kehendaknya atas tindakan tersebut, apakah akan dilaksanakan atau tidak; dan

3. Dapat mengetahui ketercelaan dari tindakan tersebut.

Dan yang kedua adanya unsur kesalahan yaitu:

Kesalahan dianggap ada, apabila ia sengaja atau karena ia lalaian telah melakukan perbuatan yang mengakibatkan keadaan atau akibat yang dilarang oleh hukum pidana dan dilakukan dengan mampu bertanggung jawab. Kesalahan dan kelalaian seseorang dapat diukur dengan apakah pelaku tindak pidana itu mampu bertanggung jawab, yaitu bila tindakannya itu memuat empat unsur yaitu:

1. Melakukan perbuatan pidana dan memenuhi unsur-unsur pidana (sifat melawan hukum);

2. memenuhi umur tertentu untuk mampu bertanggung jawab:

3. Memiliki satu bentuk kesalahan yang merupakan kesengajaan (dolus) dan kealpaan/kelalaian (culpa);

4. Tidak mempunyai alasan pemaaf.

Yang disini kesengajaan dibagi menjadi tiga jenis yaitu:

1. Sengaja memiliki niat (Oomerk)

Bahwa dengan kesengajaannya yang bersifat mencapai tujuan (oogmerk) si pelaku dapat dimintai pertanggungjawabkan, mudah dapat dimengerti oleh orang-orang awam. Maka apabila kesengajaan semacam ini ada pada suatu tindak pidana, tidak ada yang tidak mengakui, bahwa si pelaku memang harus dikenakan hukuman pidana ini lebih terlohat apabila dikemukakan, bahwa dengan adanya kesengajaan yang bersifat tujuan ini, dapat dibilang si pelaku benar-benar mengkehendaki perbuatan untuk mencapai akibat yang menjadi pokok alasan diadakannya ancaman hukum pidana (constitutief gevolg).

2. Sengaja dengan Kepastian (zekerheidsbewustzijn) 
Kesengajaan sejenis ini ada apabila si pelaku dengan perbuatannya, tidak bertujuan untuk mencapai akibat yang menjadi dasar dari delict, tetapi ia mengetahui benar, bahwa akibat itu pasti akan terjadi dan muncul.

3. Sengaja dengan Kemungkinan (Dolus eventualis, mogelijkeheidsbewustzijn)

Seseorang melakukan suatu perbuatan pidana dengan maksud untuk menimbulkan suatu akibat tertentu, tetapi disamping itu ia sadar bahwa ia mungkin akan mengakibatkan suatu tindak pidana yang lainnya yang tidak diharapkan.

Kealpaan/ Kelalaian merupakan salah satu bentuk kesalahan yang timbul karena pelakunya tidak memenuhi standar perilaku yang telah ditentukan menurut undangundang, kelalaian itu terjadi dikarenakan perilaku orang itu sendiri. Kelalaian menurut hukum pidana terbagi dua macam yaitu:

1. Kealpaan perbuatan, apabila hanya dengan melakukan perbuatannya sudah merupakan suatu peristiwa pidana, maka tidak perlu melihat akibat yang timbul dari perbuatan tersebut sebagaimana ketentuan Pasal 205 KUHP;

2. kealpaan akibat, merupakan suatu peristiwa pidana kalau akibat dari kealpaan itu sendiri sudah mengakibatkan akibat yang dilarang oleh hukum pidana, misalnya cacat atau matinya orang lain sebagaimana yang diatur dalam Pasal 359, 360,361 KUHP.

Unsur-unsur kealpaan, yaitu:

1. Pelaku melakukan berbuat lain dari apa yang seharusnya diperbuat menurut hukum tertulis maupun tidak tertulis, sehingga sebenarnya ia telah melakukan suatu perbuatan (termasuk tidak berbuat) yang melawan hukum; 
2. Pelaku telah berlaku kurang hati-hati dalam bertindak, ceroboh dan kurang berpikir panjang; dan

3. Perbuatan pelaku itu dapat dihukum, oleh karena itu pelaku harus bertanggung jawab atas akibat dari perbuatannya tersebut.

kealpaan (culpa), pada umumnya, dibedakan atas :

1. Culpa dengan kesadaran. kelalaian yang disadari, contohnya antara lain sembrono (roekeloos), lalai (onachttzaam), tidak acuh. Dimana seseorang sadar akan risiko, tetapi berharap akibat buruk tidak akan terjadi;

2. Culpa tanpa kesadaran, kelalaian yang tidak disadari, contohnya antara lain kurang berpikir (onnadentkend), lengah (onoplettend), dimana seseorang seyogianya harus sadar dengan risiko, tetapi tidak demikian.

Jadi kelalaian yang diketahui atau disadari terjadi jika seseorang tidak memenuhi suatu perbuatan, namun dia tahu apabila dia tidak memenuhi perbuatan tersebut, maka akan menimbulkan akibat yang dilarang dalam hukum pidana. Sedangkan kealpaan yang tidak disadari terjadi apabila pelaku tidak sama sekali memikirkan kemungkinan adanya suatu akibat dari perbuatanya atau keadaan tertentu, dan apabila ia telah memikirkan hal itu sebelumnya maka ia tidak akan melakukannya.

Dalam hal ini pihak syabandar khususnya pihak syahbandar Muara Angke melakukan kealpaan dengan kesadaran yaitu kelalaian yang disadari, contohnya antara lain sembrono (roekeloos), lalai (onachttzaam), tidak acuh. Dimana seseorang sadar akan risiko, tetapi berharap akibat buruk tidak akan terjadi. Dan memenuhi Unsur-unsur kealpaan yaitu:

1. Pelaku melakukan lain dari apa yang seharusnya diperbuat berdasarkan hukum tertulis maupun tidak tertulis, sehingga pada dasarnya ia telah melakukan suatu perbuatan (termasuk tidak berbuat) yang melawan hukum; 
2. Pelaku melalukan suatu perbuatan dan tidak berlaku kurang hatihati, ceroboh dan kurang berpikir panjang; dan

3. Perbuatan pelaku itu dapat dihukum, maka dari itu pelaku harus bertanggung jawab atas akibat dari perbuatannya tersebut.

Tenggelamnya kapal KM zahro express pihak syabandar memenuhi unsur kealpaan pada Pasal 359 KUHP: “ Barangsiapa karena (kealpaannya) menyebabkan orang lain mati diancam dengan pidana paling lama lima tahun atau pidana kurungan paling lama satu tahun", syahbandar sudah diberi fungsi, tugas dan wewenang oleh undangundang sebagai mestinya namun pihak syabahdar tidak melakukannya yaitu melakukan pengecekan atau pengawasana akibat kelalaiannya tersebut yang dimana ia seharusnya menyadari resiko jika tidak melakukan pengecekan atau pengawasan sebelum ia mengeluarkan izin berlayar untuk kapal KM zahro express sehingga menimbulkan kerugian dan kematian kepada penumpang kapal KM zahro express.

Mengenai pertanggungjawaban pidana oleh pemilik kapal sudah diatur oleh Undang-undang Nomor 17 Tahun 2008 Tentang Pelayaran misalnya pada Pasal 103 yang berbunyi:

1. Setiap kapal yang sudah mendapatkan sertifikat sebagaimana dimaksud dalam Pasal 126 ayat (1) wajib dipelihara sehingga tetap memenuhi persyaratan keselamatan kapal.

2. Menjaga dan pemeliharan kapal sebagaimana dimaksud pada ayat (1) dilakukan secara berkala dan sewaktu-waktu.

3. Dalam keadaan tertentu Menteri dapat memberikan pembebasan sebagian persyaratan yang ditetapkan dengan tetap memperhatikan keselamatan kapal.

Serta ancaman pidana mengenai tidak dipeliharanya kapal yang sudah mendapatkan sertifikat laiklautan yang ada pada Pasal 305 yang berbunyi: Setiap orang yang tidak memelihara kapalnya sehingga tidak memenuhi sesuai persyaratan keselamatan kapal 
sebagaimana dimaksud dalam Pasal 130 ayat (1), dipidana dengan pidana penjara paling lama 6 (enam) bulan atau denda paling banyak Rp100.000.000,00 (seratus juta rupiah). dan Pasal 303 Undang-undang Nomor 17 Tahun 2008 Tentang Pelayaran berbunyi "Setiap orang yang tidak memelihara kapalnya sehingga tidak memenuhi sesuai persyaratan keselamatan kapal sebagaimana dimaksud dalam Pasal 130 ayat (1), dipidana dengan pidana penjara paling lama 6 (enam) bulan atau denda paling banyak Rp100.000.000,00 (seratus juta rupiah).”

Sedangkan Pasal 303 berbunyi sebagai berikut:

1. Setiap orang yang mengoperasikan kapal dan pelabuhan tanpa memenuhi persyaratan keselamatan dan keamanan pelayaran serta perlindungan lingkungan maritim sebagaimana dimaksud dalam Pasal 122, dipidana dengan pidana penjara paling lama 2 (dua) tahun dan denda paling banyak Rp300.000.000,00 (tiga ratus juta rupiah).

2. Jika perbuatan sebagaimana dimaksud pada ayat (1), mengakibatkan kerugian harta benda dipidana dengan pidana penjara paling lama 4 (empat) tahun dan denda paling banyak Rp500.000.000,00 (lima ratus juta rupiah).

3. Jika perbuatan sebagaimana dimaksud pada ayat (1) mengakibatkan kematian seseorang, dipidana dengan pidana penjara paling lama 10 (sepuluh) tahun dan denda paling banyak Rp1.500.000.000,00 (satu miliar lima ratus juta rupiah).

Selain dari ke dua pasal diatas ada juga Undang-undang Nomor 51 Tahun 2002 Tentang perkapalan mewajibkan nakhoda termasuk didalamnya adalah pemilik kapal untuk memelihara dan wajib melimbungkan kapalnya sesuai dengan jadwal.

Pasal 58 Undang-undang Nomor 51 Tahun 2002 Tentang Perkapalan berbunyi sebagai berikut: 
1. Pemilik, operator, nakhoda atau pemimpin kapal wajib memelihara dan merawat kapalnya sehingga kapal selama dioperasikan tetap memenuhi persyaratan keselamatan kapal dan sesuai dengan data yang terdapat pada sertifikat kapal.

2. Setiap kapal wajib dilimbungkan sesuai dengan jadwal yang ditentukan untuk pelaksanaan pemeliharaan sebagaimana dimaksud dalam ayat (1).

3. Ketentuan lebih lanjut mengenai pemeliharaan dan perawatan sebagaimana dimaksud dalam ayat (1) dan ayat (2) diatur dengan Keputusan Menteri.

Berdasarkan kronologis kasus diatas kapal mengalami kebakaran dibagian mesin yang disertai ledakan akibat tidak dipenuhinya keliklautan kapal itu sendiri. Nakhoda bukan merupakan pemilik kapal namun sebagai nakhoda sesuai dengan kesepakatan kerja antara pemilik kapal KM Zahro Express dengan MN selaku nakhoda hanya menjalankan tugas sesuai dengan perintah yang diberikan oleh pemilik kapal. Namun nakhoda diberi bagian tanggungjawab dalam aspek keselamatan dan keamanan oleh Undang-undang yang cukup besar porsinya bahkan pada Pasal 249 Undang-undang Nomor 17 Tahun 2008 Tentang Pelayaran bahwa nakhoda bertanggungjawab penuh jika terjadi kecelakaan kapal. Kecuali dapat dibuktikan lain. Namun ada pertanggungjawaban yang bukan merupakan porsi nakhoda dalam hal keselamatan dan keamanan, ada juga yang merupakan porsi tanggungjawab yang diberikan ke pemilik kapal yaitu dalam hal memelihara kapal yang diamanatkan oleh Undangundang pada Pasal 130 Undang-undang Nomor 17 Tahun 2008 Tentang Pelayaran yang berbunyi:

1. Setiap kapal yang memperoleh sertifikat sebagaimana dimaksud dalam Pasal 126 ayat (1) wajib dipelihara sehingga tetap memenuhi persyaratan keselamatan kapal.

2. Pemeliharaan kapal sebagaimana dimaksud pada ayat (1) dilakukan secara berkala dan sewaktu-waktu. 
3. Dalam keadaan tertentu Menteri dapat memberikan pembebasan sebagian persyaratan yang ditetapkan dengan tetap memperhatikan keselamatan kapal.

Dalam hal pemenuhan kelaiklautan seperti yang dijelaskan diatas dengan ancaman pidana. Seharusnya pemilik kapal mengetahui bahwa dia bertanggungjawab dalam pemenuhan kelaiklautan kapal dan memelihara kelaiklautan kapal yang sudah mendapatkan sertifikat keselamatan dan keamanan seperti yang ada Pasal 130 Ayat 2 Undang-undang Nomor 17 Tahun 2008 tentang Pelayaran yang berbunyi:

1. Setiap kapal yang memperoleh sertifikat sebagaimana dimaksud dalam Pasal 126 ayat (1) wajib dipelihara sehingga tetap memenuhi persyaratan keselamatan kapal.

2. Pemeliharaan kapal sebagaimana dimaksud pada ayat (1) dilakukan secara berkala dan sewaktu-waktu.

3. Dalam keadaan tertentu Menteri dapat memberikan pembebasan sebagian persyaratan yang ditetapkan dengan tetap memperhatikan keselamatan kapal.

Maka pemilik dalam hal ini kealpaan dengan kesadaran yang dimana sama dengan pihak syahbandar bahwa pemilik kapal mengetahui bahwa ia diberi tanggungjawab oleh Undang-undang untuk memelihara kapalnya supaya yang harus dipenuhi dalam rangka untuk keselamatan dan keamanan penumpang maupun muatan barang namun ia tidak memenuhi tanggungjawab tersebut, pemilik kapal selain memenuhi unsur kelalaian yang menyebabkan hilangnya nyawa yang ada pada Pasal 359 KUHP yang berbunyi: "Barangsiapa karena kealpaannya menyebabkan matinya orang lain, diancam dengan pidana penjara paling lama lima tahun atau kurungan paling lama satu tahun" sesuai dengan Pasal 305 Undang-undang Nomor 17 Tahun 2008 Tentang Pelayaran jika pemilik tidak memelihara kapalnya sehingga tidak memenuhi syarat keselamatan maka dipidana penjara dan denda.selain dari pada Pasal diatas pemilik kapal juga memenuhi unsur-unsur pidana pada Pasal 303 Undang-undang Pelayaran yang berbunyi: 
1. Setiap orang yang mengoperasikan kapal dan pelabuhan tanpa memenuhi persyaratan keselamatan dan keamanan pelayaran serta perlindungan lingkungan maritim sebagaimana dimaksud dalam pasal 122, dipidana dengan pidana penjara paling lama 2 (dua) tahun dan denda paling banyak Rp300.000.000,00 (tiga ratus juta rupiah).

2. Jika perbuatan sebagaimana dimaksud pada ayat (1), mengakibatkan kerugian harta benda dipidana dengan pidana penjara paling lama 4 (empat) tahun dan denda paling banyak Rp500.000.000,00 (lima ratus juta rupiah).

3. Jika perbuatan sebagaimana dimaksud pada ayat (1) mengakibatkan kematian seseorang, dipidana dengan pidana penjara paling lama 10 (sepuluh) tahun dan denda paling banyak Rp1.500.000.000,00 (satu miliar lima ratus juta rupiah).

maka pemilik kapal dalam hal ini bertanggungjawab secara pidana berdasarkan Pasalpasal diatas.

\section{PENUTUP}

\section{A. Kesimpulan}

Kelaiklautan jika berdasarkan Undang-undang Nomor 17 Tahun 2008 Tentang Pelayaran adalah kondisi kapal yang memenuhi standar keselamatan kapal, pengawakan, batas muat, pemuatan kapal, kesejahteraan Awak Kapal dan kesehatan penumpang, status hukum kapal, pencegahan pencemaran perairan dari kapal manajemen keselamatan dan pencegahan pencemaran dari kapal, dan manajemen keamanan kapal untuk berlayar di perairan tertentu. Dalam mengoperasikan kapal tidak hanya satu pihak yang terkait namun beberapa pihak juga terkait baik itu secara langsung maupun tidak langsung begitu juga dalam pemenuhan kelaiklautan kapal, termasuk jika terjadi kecelakaan kapal pihak-pihak yang terkait akan 
mempertanggungjawabkan sesuai dengan porsi masing-masing yang sudah diatur oleh Undang-undang. kecelakaan yang dialami KM Zahro Express ada beberapa pihak terkait yaitu nakhoda, pemilik kapal, dan syahbandar.

Nakhoda menjadi pihak yang bertanggungjawab secara pidana dan didakwa beberapa Pasal termasuk melanggar Pasal 302 Undang-undang Nomor 17 Tahun 2008 Tentang Pelayaran, nakhoda tetap mengoperasikan kapal yang tidak laiklaut. Namun tidak hanya nakhoda, pemilik kapal dan syahbandar juga menjadi pihak yang bertanggungjawab secara pidana karena lalai/kealpaan yang diatur oleh Pasal 359 KUHP. Dalam kecelakaan kapal Km Zahro Express. Pihak syahbandar tetap meloloskan kapal KM Zahro Express yang tidak laiklaut untuk tetap berlayar dengan mengeluarkan surat izin berlayar kepada nakhoda tanpa mengecek secara fisik kapal tersebut terlebih dahulu. Begitu juga dengan pemilik kapal yang mengetahui bahwa kapal KM Zahro Express tidak laiklaut dan mengetahui akan resiko yang akan timbul, namun tetap melayarkan kapal tersebut.

\section{B. Saran}

Berdasarkan paparan yang telah dijabarkan oleh penulis, maka penulis mengutararakan saran, sebagai berikut :

Terjadinya kecelakaan kapal seperti yang terjadi pada KM Zahro Express bukan hanya pihak yang terkait langsung seperti nakhoda untuk memenuhi kelaiklautan, namun pihak yang tidak terkait langsung seperti pemilik kapal dan syahbandar juga mempunyai tanggungjawab dalam pemenuhan kelaiklautan itu. Undang-undang memberikan fungsi, tugas dan wewenang pada masing-masing pihak untuk melakukan tugas Sama seperti hal jika terjadi kecelakaan akibat tidak laiklaut. Pihakpihak terkait harus bertanggungjawab sesuai dengan porsinya, tidak hanya nakhoda saja yang secara kenyataan ia mengemudikan kapal tersebut. 


\section{DAFTAR PUSTAKA}

Fajar, Mukti dan Yulianto Achmad. Dualisme Penelitian Hukum Normatif \& Empiris, cetakan ke-3, Yogyakarta: Pustaka Pelajar, 2015.

Ibrahim, Johnny. Teori \& Metodologi Penelitian Hukum Normatif, Malang: Bayumedia Publishing, 2006.

Marzuki, Peter Mahmud, Penelitian Hukum, Jakarta: Kencana Prenada Media Grup, 2008.

Marzuki, Peter Mahmud. penelitian hukum edisi revisi. Jakarta: kencana Prenada Media Grup, 2005.

Soekanto, Soerjono. Pengantar Penelitian Hukum Cetakan ke-3, Jakarta: UI-Pres 1986.

Silalahi, M. Daud, Pengaturan Hukum Lingkungan Laut Indonesia dan Implementasinya Secara Regional, Jakarta: Sinar Harapan, 1992.

Prabowo, Dani. Jokowi fokus bangun tol laut untuk pemerataan. https://nasional.kompas.com/read/2014/06/15/2140590/Jokowi.Fokus.Bangu n.Tol.Laut.untuk.Pemerataan. diakses 09 Juli, Pukul 11.28.

Utomo, Hari. Jurnal: Siapa yang bertanggung jawab menurut hukum dalam kecelakaan kapaL. (Legally Responsible Parties In Ship Accident), http://ejurnal.peraturan.go.id/index.php/jli/article/download/75/pdf, hal 57, diakes 09 Juli 2018, Pukul 10.38. 